\title{
The Concretization of the Literary Work of Art: Elements for a Comparison between Roman Ingarden and Wolfgang Iser
}

\author{
Sazan Kryeziu
}

University of Gjakova "Fehmi Agani", Faculty of Philology, Department of English Language and Literature, Ismail Qemali St., n.n, 50 000, Gjakova, Kosovo

https://orcid.org/0000-0003-0137-9932

sazan.kryeziu@uni-gjk.org

The notion of concretization introduced by Roman Ingarden in his seminal work The Literary Work of Art makes the reader the one responsible for the creation of the literary work of art as an aesthetic object. Prior to the act of reading, the work itself,' in Ingarden's analysis, is a structure of various strata: the stratum of verbal sounds, the stratum of meaning units, the stratum of schematized aspects, and the stratum of represented objectivities. The reader concretizes the work, turning the schematic formation into an accomplished aesthetic object. Concretization is accomplished by adding determinations to the schemata of the text on all strata. By way of their psychic operations readers fill in places of indeterminacy and establish the world of the literary work of art. Wolfgang Iser takes up Ingarden's concept of places of indeterminacy to develop his own position. Iser recasts the concept of indeterminacy in the form of gaps or 'blanks' which allow for more functions and forms than those stated in Ingarden's analysis. For Ingarden, the process of reading moves in one direction: from the real world to the imaginary (intentional) world. For Iser the process of reading is two-directional: the reader fills in the blanks of the imaginary world using the memory traces collected in his or her mind that derive from the life-world. An attempt to clarify the main points of Ingarden's phenomenology of reading, may, therefore, elucidate Iser's contribution. In addition, the notion of concretization has seen many criticisms (R. Wellek, G. Poulet, S. Fish, D. Barnouw among others), and the topic deserves renewed attention.

Keywords: literary theory / phenomenology of reading / places of indeterminacy / concretization / Ingarden, Roman / Iser, Wolfgang 
The confrontation with Roman Ingarden (1893-1970) and Wolfgang Iser (1926-2007) that we are about to undertake has been made necessary by the emergence of a problem resulting from Ingarden's conception presented in his The Literary Work of Art (1931), in that, the work of art as a purely intentional intersubjective object finds its fulfillment as a 'polyphonic harmony' through the experience of the reader's thinking and phantasy (its concretization). For Ingarden, a text does not have a fully determined content (that is, it is not complete), first of all, in the sense that it contains 'variables' or 'schematic views' that readers are asked to fill in or 'concretize'. Readers attempt to picture the characters and the events present in the text. The natural attitude of the reader, for Ingarden, tends toward the elimination of spots or 'places of indeterminacy' (Unbestimmtheitsstellen) by way of concretization. Second, a text is incomplete in the sense that the world of the art work is an intentional correlate of a sequential chain of sentences which intends a unity for such a world to be intended. Taking up Husserl's theory of temporality and applying it to the sequence of sentences in a literary text, Ingarden contends that each sentence points beyond itself, thus by opening up a perspective it calls for the reader to put it into the play of her expectations, and by doing this she will be able to modify them, yet not to fulfill them. This changing process of the horizon of expectations forms the so called 'image-building concretization.'

In The Act of Reading (1978), Wolfgang Iser takes up Ingarden's concept of structural indeterminacy to develop his own position. Iser recasts the concept of indeterminacy in the form of gaps or 'blanks' which allow for more functions and forms than those stated in Ingarden's analysis. Blanks occupy an important place in the communicative function of a literary work, since they "induce the reader to perform basic operations within the text" (Iser, The Act 169). By filling in, completing, or removing blanks on several levels, the reader thus creates or co-creates the literary work, or to follow Iser, "the asymmetry between text and reader stimulates a constitutive activity on the part of the reader; this is given a specific structure by the blanks and the negations arising out of the text, and this structure controls the process of interaction" (169-70). Iser's conception of indeterminacy in literary works has been criticized most forcefully by Stanley Fish, among others. Another important concept in Iser's The Act of Reading is that of the 'wandering viewpoint,' the treatment of which will also occupy part of our discussion. Taking his cue from Husserl's analysis of the interplay of retentions and protentions, Iser's 'wandering viewpoint' 
expresses the idea that the text cannot be perceived all at once, and that, by operating within the literary text, we can travel with the text as our reading progresses.

Notwithstanding the illuminating theories of these phenomenologies of reading brought forward by Ingarden and Iser, we will also discuss the following problem: if the reader is guided, stimulated or reinforced to adopt a position in relation to the text (Iser, The Act 169), then does this reading strategy of the "disappearing text bring about the disappearance of the reader, too?" (Barnouw 1979). Contrary to this view, my thesis assumes that what modernist theorists and literary critics call disappearance of text and reader in the act of reading, is in fact a radical transformation of the reader, put differently, the transformation of text has brought about the reader's transformation. But in order to be able to make some sense of this thesis in the concluding part of the paper, we should first present and confront Ingarden and Iser's theories on the phenomenology of the act of reading.

I.

Phenomenology tries to determine that one cannot describe an object in its wholeness if that object is observed from one perspective only, but rather it is necessary to observe it from multiple perspectives if we want to have the closest descriptions possible. In the same way: many perspectives are integrated in a unit of meaning which is recognized as the material object. Thus, in a literary text, the multiplicity of perspectives does not coincide with the same potency on the intentional object. The artist's imagination cannot incorporate all aspects of the material object to the text; therefore, many places or gaps are left to be filled by the reader's concretization of the work.

Ingarden's preoccupation with the issue of concretization began once he finished analyzing in great detail the problem of the structure of the literary work, and before moving toward the problem of aesthetic value qualities. The first question that Ingarden raises is: how does a literary work appear during reading, and what is the immediate correlate of this reading? (Ingarden, Literary 332). And he provides the answer directly, positing that concretization is "precisely what is constituted during the reading and what, in a manner of speaking, forms the mode of appearance of a work, the concrete form in which the work itself is constituted" (332). Apart from the traditional distinction between the work of art and its material foundation, Ingarden differen- 
tiates two additional objects within the intentional mode of being: the work of art itself and its concretization, which for Ingarden is the real aesthetic object. This proposition is Ingarden's fundamental discovery in the field of aesthetics: that the art work is a 'schematized object' created by the artist with the intention of reaching its fullness of existence and realization, and thus becoming an aesthetic object for the observer. This proposition of Ingarden is contrary to Husserl's theory according to which even non-intentional phenomena (material entities) are considered as intentional, because they are immanent through the perception of the observing subject.

Yet, instead of indicating what a concretization of a literary work of art actually is, Ingarden, first of all, sets himself the task of describing the properties of the concretization of a literary work and points out the relationships, on the one hand between the concretization and the literary work, and on the other between the concretizations and the subjective experiences in which they are constituted (Ingarden, Literary 332). Since the schematization of a literary work is of a very diverse yet complex structure of heterogeneous elements brought about in various combinations, we therefore deal with various possible concretizations that are its substantiated forms. It should be pointed out that both the literary work of art and its concretizations are different from the experiences of apprehension. As emphasized by Ingarden: "there would be no concretizations if such experiences of apprehension were not effected, since concretizations are dependent on the latter, not simply in their mode of existence, but in their matter as well" (335).

The literary work of art is a schematic formation, and some of its strata, especially the objective stratum, contain some blank spots, appearing on the basis of a complex chain of sentences. The represented objects in a literary work of art are intended as real objects hence they might be taken to be part of the same ontology as the real objects. This does not stand, however, because represented objects in a literary work are objects represented intentionally (that is, they are only projected as concrete entities), and as such they can have only those properties that arise from the text. Thus, we can access a text only from the ideas or things constituted in the text: if an object property is not mentioned, it remains undetermined and undeterminable, therefore, intentional objects represented in the literary work of art are said to contain a series of spots or 'places of indeterminacy.' As Ingarden puts it in The Cognition of the Literary Work of Art. 
We find such a place of indeterminacy wherever it is possible, on the basis of the sentences in the work, to say whether a certain object or objective situation has a certain attribute. If, for instance, the color of Consul Buddenbrook's eyes were not mentioned in Buddenbrooks (and I have not checked to see), then he would be completely undetermined in this respect. We know implicitly, through context and by the fact that he is a human being and has not lost his eyes, that his eyes are of some colour, but we do not know which...I call the aspect or part of the portrayed object which is not specifically determined by the text a 'place of indeterminacy.' (50)

Hence, reading, in a sense, consists of making more complete the schematic aspects in the text. This completion (or realization), according to Ingarden, may be achieved in conjunction with concretization. ${ }^{1}$ The theory of concretization enables the reader to relate the abstracted model of the material object created by the artist to the original object of which it is a model. First, we must remember that represented objects are not affected by schematization or any potentiality of its aspects, rather schematization and potentiality appear on other strata of the literary work, that of meaning creation and appearances, which according to Ingarden, are 'held in readiness' (Parathaltung) by the literary work and become a reality in the reader's perception. But, as noted by Szczepańska, we must be careful not to identify a concretization with the work itself, "as it is often mistakenly interpreted by theorists or scholars” (Szczepańska 33). Rather, the reader's perception of an individual literary work always assumes the form in which it expresses

${ }^{1}$ In an instructive and illuminating account, Jeff Mitscherling (1997) observes: “The term 'concretization' has often been employed by Ingarden's commentators and critics - and indeed sometimes by Ingarden himself - in a confusing and inconsistent manner. We have to distinguish three terms: (1) realization (or actualization), (2) concretization, and (3) aesthetic object. These terms do not refer to the same object or activity. They are properly to be employed as follows: (l) That which exists potentially may be 'realized'. This realization may be achieved in conjunction with concretization, but they are different activities; the 'schematized aspect held in readiness,' for example, is 'realized' when it is no longer held in readiness but has become present, and it is by virtue of its concretization that this aspect has achieved its presence. (2) Concretization refers to the 'filling out' of that which is given only schematically in the work; both the individual (schematized) aspects of a work and the work as a (schematic) whole are said to be 'concretized' by the subject who apprehends them. (3) Regarding the use of 'aesthetic object,' we merely have to be careful not to confuse it with either the realization of possibilities or the concretization of the work" (Mitscherling 160). As Ingarden explains in The Literary Work of Art: "It is not the concretization itself which is the aesthetic object, but rather the literary work of art taken precisely as it is expressed in a concretization in which it achieves its full incarnation" (372). 
itself in the given concretization. For, if we do not turn our attention to the work itself, but to a given concretization, then we cannot be aware of the difference between the work and its concretizations. Hence, the work is only 'expressed' and 'developed' in concretizations, but each such development, as Ingarden explains "(as long as it is not a mere reconstruction of the work) necessarily goes beyond it" (Ingarden, Literary 337).

The idea that for each reading experience there can be a concretization, arises from the fact the objects of properties in a work of art remain undetermined and as such they require imaginational experience, creativity and skill. Since concretizations are said to be the activity of individual readers, they allow a vast number of variables. Further, what one reader apprehends in reading a literary work is not identical with that of another reader of the same work. Even the same reader may have different experiences of the same work. Accordingly, by assuming an aesthetic attitude toward the work (that is, growing intellectually and emotionally), we may become more able in realizing the aesthetic possibilities of a literary work. We must be attentive, however, not to confuse the use of the word 'concretization' with the word 'concretion' of the work of art. As noted by Holub: "Ingarden employs the word concretization to designate the result of actualizing the potentialities, objectifying the sense-units, and concretizing the indeterminacies in a given text" (Holub 26). On the other hand, a concretion "although conditioned in its existence by corresponding experiences in the reader, it is codetermined by the literary work" (26).

If Ingarden's aestheticism is examined closely, three main propositions will always occur: (i) that the work of art is an intentional object, (ii) the work of art consists of different strata, (iii) the perceiver (observer, reader, listener) will perform an act of concretization in order to relate the intentional object to the material object. If during the concretization process the strata are to be neglected, then this will result in incorrect apprehension and interpretation of the meaning of the work of art. The third stratum of the represented objects is of particular importance as regards the establishment of the meaning of the literary work, which also determines the 'metaphysical qualities' of a literary work of art. It is in this stratum that the artist establishes the larger context of meaning and constructs his representative objects for the reader to decode, since the reader who does not have full access to the artist's strategy of meaning in every instance, will therefore be able to apprehend the implied purpose of the artist. Yet, in Bundgaard's view: "these are questions that follow directly from Ingarden's approach, but which 
he has not himself developed in any particular way; probably because such a problem is semiotic, rather than ontological" (Bundgaard 176).

However, a literary work of art cannot be said to constitute an aesthetic object if its constitutive elements are not concretized. Hence we can distinguish three components of the aesthetic object: first, there is the existence of the material object, second, the abstracted model of the material object as created by the artist, and third, the perceiver who is encouraged to apply his own experience in order to relate the intentional object to the material object through the process of concretization. In Hans H. Rudnick observation, "it is also obvious at this point why Ingarden cannot accept Husserl's transcendental idealism which does not permit such a direct relation to the material object" (Rudnick 111).

The reader on his part begins the concretization process by using the 'fictitious realm of the state of affairs' offered to him by the third stratum, as the 'orientation space.' In this way, the reader, using all of his life experience, can fill in those gaps left incomplete by the artist's imagination in the literary text. Applying all his personal and interpretative engagement, as we already pointed out, the reader will be able to make sense of the meaning of the work of art. Yet the real meaning is concealed by the material object. So, it is the task of the reader to discover the real meaning, by attempting to discover the 'schema' offered to him through the presented objects in the art work. Meaning speaks to the reader by way of the particular schema contained in the text. Regardless of the multiplicity of aspects of reality, the task of the reader lies in his ability to see them within perspective and context. However, we must remember that such a subjective access to the text is not an assurance that one has thoroughly apprehended the work of art, for as we noted, a work of art always presents itself from a multiplicity of perspectives to the reader, and that the reader on his part can use merely a particular perspective as access to the text. Since one's experience is always emotionally and intellectually different from the experience of other readers, the observation of the intentional object is therefore of particular importance as regards the validity and depth of concretization.

The manifold aesthetic value qualities are constituted in the various strata of the literary work of art. And it is precisely by reason of this considerable diversity that they form a polyphonic harmony. Further, it is because of this diversity of aesthetic value qualities that, as Ingaden shows, "does not permit them to merge into a fused sphere of homogeneous elements such as we find in the previously distinguished strata of the work" (Ingarden, Literary 371). The work of art is this polyphonic 
entity consisting of various strata, merging into a harmonious structure, yet although "this harmony has its own completely new, derives 'Gestalt' qualities, it is still a polyphonic harmony, an aesthetic expression (if we may use this term) of the stratified structure of the literary work" (371-372). Again, the strata are interrelated and organized in such a way that they provide the reader with a 'schema' which orients him in the course of the concretization. Ingarden rejects the division of the work of art into form and content. For him, the work of art as an organic unity draws its life from the polyphonic harmony between the various strata and the reader's concretization. He also refutes the Formalists viewpoint according to which poetic language is merely a part or subdivision of linguistics. Ingarden does not deny the importance of linguistics, and what is more, he sees poetics and linguistics as intersecting phenomena. However, unlike linguistics, poetics treats the literary work of art in terms of artistic categories following a principle of its own: the figurative language, which presents itself to the reader and demands concretization from him.

A literary work of art achieves its full incarnation only if it attains adequate expression in a concretization, or to put it in Ingarden's own words, only in the concretization it can attain "a full establishment, an intuitive exhibition, of all these qualities" (Ingarden, Literary 372). Or to put it in more precise terms: "the literary work of art constitutes an aesthetic object only when it is expressed in a concretization" (372). From this we come to understand that the aesthetic object parallels the objective work of art with the subjective concretization. The aesthetic object is said to be an organic unity of the physical object (the work) and the psychological subject (the reader). The text invites the reader to concretize its nature left open by the artist's imagination. If the concretization is incorrect, then the aesthetic judgment will also result in incorrectness. However, as Rudnick puts it "this is not to be considered as a weakness in Ingarden's system, but rather eloquent proof of the flexibility of his system. The observer cannot judge the aesthetic value of a work of art as such; he can only judge the work of art on the grounds of his personal concretization" (Rudnick 116).

One literary critic who failed to see these distinctions in the thought of Ingarden is René Wellek. In his important book Discriminations: Further Concepts of Criticism (1970), Wellek mistakenly transforms Ingarden's distinctions into ontic distinctions. This is incorrect, because the strata are characterized only on the basis of their component, that is, artistic values. According to Wellek, the existence of a 'material' or structure exists only at the moment when these structures become 
aesthetically valid. This 'moment' corresponds with Ingarden's moment of aesthetic concretization. Ingarden, like Wellek, sees every material (the structures of syntax, meaning or representation) as very important to the aesthetic effectiveness or value, but it is the aesthetic concretization that determines the multiplicity of materials in establishing the value structures of the complete aesthetic object. It must be noted that all these aesthetic attitudes of the literary work of art are related to the creation of an aesthetic object (aesthetic concretization). And an aesthetic concretization on the other hand must also be authentic or as faithful as possible to that work. Menachem Brinker, in an attempt to clarify Ingarden's exposition of the aesthetic concretizations, offers a comparative evaluation of them from three different points of view:

One, an 'effective' concretization succeeds in realizing a comparatively greater number of aesthetic values or a greater unity between these values (a richer polyphonic harmony). Two, concretization which is 'closer to the work' is one that avoids filling those indeterminacies in the text that are meant to stay 'empty' and completes the other schematic structures in a way which is closer to the 'spirit of the work' (which is not, of course, the only way open to the reader). Three, a concretization that 'does justice to the work' is one that is either 'effective' or both 'effective' and 'close to the work.' (Brinker, "Two Phenomenologies” 133)

But the question that might be raised is this: how would such an adequate concretization of a literary text be possible if the schematic structure of the work allows multiple realizations or completions? First, we must not forget that concretizations differ with regard to their aesthetic value qualities. Ingarden himself states that in order for an aesthetic experience to be faithful to the given work it has to realize a specific set of conditions. For Ingraden, a concretization is 'effective' and 'closer to the work' at hand than another work, if it comprises such fulfillments that 'does justice to the work,' yet equally 'permitted' would be those which are introduced by other works as well. In Ingarden's formulation, "[ $t]$ he aesthetic experience is 'adequate' when it leads to the constitution of a concretization which is the exact embodiment of the 'idea' indicated in it" (Ingarden, Cognition 394). And when he contends that one concretization is of greater effectiveness than another, what he actually means is that it "contains a greater number of aesthetic values and a higher total aesthetic value; but the condition must be fulfilled that the aesthetic values appearing in the concretization must belong to the domain of values which lies within the scope of the possible realizations of that work of art" (368). 
However, these criteria are not without their problems. For instance, Ingarden argues that it is not impossible that, despite the equality of the value, for each criterion to have more than one concretization equally close to the work. Likewise, with regard to the criterion of effectiveness, "two aesthetic experiences of the same literary work of art which take different courses can also lead to the constitution of two concretizations having a qualitatively different but equally high aesthetic value because the same places of indeterminacy can be filled out in very different ways and, as a result, can constitute different aesthetically relevant qualities" (Ingarden, Cognition 374-75). But the problem is that, if we follow these criteria, how would one decide which concretization is the most adequate one? It seems that one adequate concretization of the literary text cannot be confined to any founded set of criteria, no matter how precise or strict they may be. For a multiplicity of equally adequate concretizations of the same work, as we already indicated, may always differ among themselves as regards their aesthetic value. No matter how many properties of an aesthetic object we have determined, there are always more to be found, because one and the same work of art authorizes its perceivers to always pass varying judgments.

\section{II.}

Iser approves of Ingarden's phenomenology for rejecting the notion of the contemplator of the art work. Ingarden substitutes this notion of classical aesthetics with the notion of concretization by making the reader the one who is responsible for the constitution of the literary work of art. The literary work of art itself is a schematized object consisting of various strata: the stratum of verbal sounds, meaning-units, schematized aspects, and the stratum of represented objectivities. The reader concretizes the work, turning the schematic formation into an accomplished aesthetic object. Yet, in Iser's view, Ingarden's ideas are still under the influence of classical aesthetics, since for Ingarden the objectivities represented in the work of art are 'purely intentional' owing their existence to the artist's intentionality, which provides a schematic basis for their being, and to the reader's intentionality, which brings these schemes into full being. Whereas in The Cognition Ingarden tries to build up the art work as a schematic formation existing independently of any aesthetic concretization.

Iser's main criticism is opposed to Ingarden's notion of 'polyphonic harmony.' According to Iser, the role of the reader would be too 
narrow if we view it as the reconstruction of a 'polyphonic harmony' existing in the work itself as Ingarden posited. With Ingarden's 'places of indeterminacy' the reader is confined within a narrow horizon of activity. In addition, a reader's concretization to the constitution of an aesthetic object is different from another aesthetic object constituted by another reader for the same work. In Iser's view, Ingarden failed to realize that gaps or blanks are the dynamic elements of the literary text. Textual indeterminacies are of great importance because they set in motion the process of reading and sustain it. And if the role of textual indeterminacies is misconstrued, then the whole way according to which the overall meaning of the fictional work is constituted, will be misconstrued, too.

Yet Iser follows Ingarden in arguing that meaning is not inherent in the text, but rather emerges in the interaction between reader and text. And he goes a little bit further in allowing for the openness of the text. The text, says Iser, is no longer a fixed object but open to an active process to be dismantled and assembled by the mind of the reader. However, if a work is no longer autonomous but dependent on the reader for its reconstruction, the first question that comes to our mind is: how is this activity conducted and what happens to the reader in all this process?

Iser's The Act of Reading attempts to answer these questions by revealing how reading sets in motion a series of activities that depend on human mind and how a text's potentiality reaches its fullness and realization during the reading process. Initially, he argues that the structures of the work "do not fulfill their function until they have affected the reader" (Iser, The Act 21). Iser recasts the phenomenon of textual indeterminacy in the form of 'blanks' or 'gaps' (Leerstellen) since they point to the necessity of the reader to constitute the meaning of the text. These gaps are encountered both at the thematic level and at the level of textual strategies. A literary text is said to be a result of the interaction between the text and the reader. In order to clarify the nature of this process, Iser uses the concept of 'the implied reader' which has "its roots firmly planted in the structure of the text" (34). As noted by Iser, 'the implied reader' "designates a network of response-inviting structures, which impel the reader to grasp the text" (34), however this reader is only "a construct, and in no way is to be identified with any real reader" (34). In his interaction with the text, the reader is invited to remove or complete the gaps on a number of levels, from simple plots to complex themes in the text which emerge against an implicit horizon. By 'implied reader' we must understand the role assigned to 
the real reader by the instructions of the text. For Iser, a literary text is an act of communication which generates "the imaginary correction of deficient realities" (85). This function of literature is offered by considering certain novels (like Joyce's Ulysses), which Iser calls 'systems of perspectives.' These 'systems of perspectives' orient the reader toward 'the text's repertoire' (through a selection of social, historical or cultural aspects). This is how Iser illustrates his technique of 'the text's repertoire' in Joyce's Ulysses: "The repertoire of this novel both reflects and reveals the rules that govern its own communication. The reader is made aware of the basic features of his mode of perception: porous selectivity, dependence on perspective, habitual reflexes. In order to orient ourselves, we constantly and automatically leave things out, but the density of the repertoire in Ulysses prevents us from doing this. Furthermore, the successive changes of style, each restricted to its own perspective, indicate the extent to which perception and interpretation depend upon the standpoint of the observer" (84).

With the modern novel, the act of reading seems to have become a technique of deception characterized by negated possibilities of meaning. This strategy depends on the reader's own efforts, awareness and willingness to configure the text. Following this strategy, as Paul Ricoeur succinctly observes, "reading itself becomes a drama of discordant concordance, inasmuch as the 'places of indeterminacy' (Unbestimmtheitstellen) - to borrow Ingarden's expression-not only designate the lacunae of the text with respect to image-building concretization, but are themselves the result of the strategy of frustration incorporated in the text as such on its rhetorical level" (Ricoeur 169). Yet the organization of the structure of meaning also depends on the strategies of the text which "lay down the lines along which the text is to be actualized" (Iser 85). In this way, however, with the modern novel, reading tends to become "a picnic where the author brings the words and the readers the meaning" (Ricoeur 169).

These textual strategies seem to be supportive of the repertoire, since their function is to establish the structure of comprehension, that is to say, to organize the references of the repertoire so that the reader could fulfill the perspectives offered, "in order for the communication to be successful" (Iser 87), because "the ultimate function of the strategies is to defamiliarize the familiar" (87). This process of the "defamiliarization of the familiar' by the reader, in Ricoeur's view "corresponds to that of depragmatizing on the side of the text and its implied author" (Ricoeur 169). Iser, however, in talking about the textual strategies, is not concerned with the techniques themselves, but rather with the "structure 
underlying them" (Iser 87). This examination leads to the discussion on the role of the reader and how his role emerges from the interaction of perspectives. In absence of links between perspectives in the text, the reader therefore is encouraged to fill in the blanks with possible links.

To this interaction process is then added the mobility of the reader's 'wandering viewpoint' according to which, the reader by placing himself within the text, travels with it as his reading activity progresses. The reader assembles the story as an imaginary object using his 'wandering viewpoint.' His viewpoint wanders along the perspectives given in the text as he attempts to join them at the aesthetic object created by himself. And while constituting in this way the overall meaning of the text, the reader achieves the level of significance. ${ }^{2}$ During the process of 'gestalt-forming,' the act of reading is experienced by the reader as a living event (Iser, The Act 128). This participation in the text in which the reader watches himself being involved enables him to become conscious of himself, which is an "essential quality of the aesthetic experience" (134). For the relevance of aesthetic experience, as Iser asserts, lies in the fact that "it induces this observation, which takes the place of codes that otherwise would be essential for the success of communication" (134).

The world of the literary texts is varied: not all texts are instructive, some of them are divertive, and as such many of them depend on a much wider range of strategies of participation on the side of the reader - not just strategies that prompt mental processes. One theoretician and literary critic who challenged Iser's theory of the act of reading is, Stanley Fish. In a diacritics review on Iser's The Act of Reading under the title "Why no one's afraid of Wolfgang Iser" (1981), Fish raised the problem in a metacritical level by arguing that the problem with Iser's theory of reading lies in its assumption that some features of text come

${ }^{2}$ As Menachem Brinker explicates: “The 'overall meaning' of the fictional work, a basic textual blank which is constituted by the reader as an imaginary object, is always referential as it points to the limitations of accepted ideologies. Its constitution may change the reader. At the beginning of reading the reader is conscious of himself as standing against the text. But this subject-object duality disappears when he becomes involved in his reading and senses himself as the constitutor of the imaginary object. At the end of the reading process there is a new duality located in the reader himself. The reader who has left his own system of beliefs and norms after realizing that they will not help him find the system of equivalences necessary for the understanding of the work encounters his own empirical self by realizing the difference between the system of equivalences embodied in the overall meaning of the work and his own norms and beliefs. This realization invites the reader to a reshaping of his personality and may cause it" (Brinker, "Two Phenomenologies” 208). 
into being through an interaction with the reader's activity, yet in other moments "Iser insists on the brute-fact of the text, at least insofar as it provides directions for the assembling of the "virtual object"” (Fish 6). Thus the objective structures which Iser assumes that determine or pave the way to the reader's response may be valid only for certain practices of reading. Readers are encouraged to fill in the gaps, but in Fish's view "gaps are not built into the text, but appear (or do not appear) as a consequence of particular interpretive strategies, then there is no distinction between what the text gives and what the reader supplies; he supplies everything; the stars in a literary text are not fixed; they are just as variable as the lines that join them" (7). The reader or author cannot supply everything, and even the "adventures of the reader's wandering viewpoint", according to Fish, "will be the products of an interpretive strategy that demands them, and therefore no one of those components can constitute the independent given which serves to ground the interpretive process" (7).

In Fish's estimation, Iser's theory of indeterminacy "loses its force because it would make just as much sense to say that everything is determinate" (11). Textual interpretation cannot be a subjective activity, on the contrary, "there is no subjectivist element of reading, because the observer is never individual in the sense of unique or private, but is always the product of the categories of understanding that are his by virtue of his membership in a community of interpretation" (11). In fact, what Fish rejects is the theory of indeterminacy on the same basis that he rejected determinacy. Since readers always operate within an interpretive structure, and given that we are always dependent on certain conventions, indeterminacy is therefore impossible. However, Fish does not say that the analysis of a literary text is impossible if following Iser's model. A textual interpretation may be conducted using a distinction between what is given in a text and the reader's contribution. But any such account might in itself be merely the result of an eventual interpretive strategy which would be valid only within a particular system of comprehensibility or accessibility.

In a response entitled "Talk like Whales" (1980), Iser had actually replied to Fish's first critique and had clarified his terms by setting up the following distinction: "The words of a text are given, the interpretation of the words is determinate, and the gaps between the given elements and/or interpretations are the indeterminacies" (83). By way of this explanation, Iser wants to distinguish between our interplay with the text and our interplay with the real world. The real world is given through the senses, "whereas the literary text is only perceivable 
through the imagination" (72), indeterminacy goes into the 'gaps' between interpretations and the given elements. The literary text, on the other hand, enables us to produce a world, that is to say, the real world is the result of interpretation. Jonathan Culler, however, thinks that this response of Iser's is "clearly unsatisfactory, since in many cases the interpretation of certain words is quite indeterminate, and often the question of what word one is dealing with is a matter of interpretation, not a given" (Culler 76).

A substantive critique of Iser's theory of aesthetic response which I would like to present here is that of Dagmar Barnouw (1979). Barnouw opens her review by raising a question which might sound a bit hyperbolic: "Is there anything left to read for Iser's reader?" She focuses on three objections: initially, questioning Iser's assertion in The Act of Reading, that "a theory of response has its roots in the text; a theory of reception rises from a history of readers' judgments," Barnouw remarks that "the text disappears increasingly in Iser's attempts at describing the dynamics of the reading process, what he terms the 'act of reading"' (Barnouw 1207). As a consequence, "with the disappearing text, the reader whose activity is to be stimulated, guided and reinforced by the text, disappears too" (1207). Secondly, in Barnouw's estimation, Iser's understanding of the reading process is insufficient, for "there are very few texts that Iser's reader can profitably read" (1207). Iser's theory thus is based on a "very selective reading of very selective texts and speculations about the mechanisms of a reading mind," and as a result Iser's concept of the interaction between text and reader can be said to presuppose that kind of the reader "who is not in the habit of reading, the reader as tabula rasa" (1207). And third, she remarks that "a theory of aesthetic response that loses sight of both text and reader in its attempts at metaphorical celebration of their dynamic interaction will not (as Iser hopes) facilitate 'intersubjective discussion of individual interpretations' nor will it 'promote reflection on presuppositions operative both in reading and interpreting"' (1207).

For Barnouw, Iser's concept of the theory of response is merely a 'corrective' to Roman Ingarden's concept of concretization "through an optimal reader" (Barnouw 1208). In Barnouw's understanding, Ingarden's concept of optimal reader "presupposes the distinction between a bad/wrong and a good/right reader resulting in an impossibly purged as well as ambiguous concept of an optimal reconstruction of the text" (1208). Though Ingarden is right to "attack the relativistic 'psychologism' of critics," his 'remedy' nevertheless "will only 
add to the problems" (1208). There are of course similarities between Ingarden's and Iser's concept of reading and reader, and that Iser "replaces" Ingarden's concept of "the harmonious complexity of the text with a modern one" in so far as the text for Iser "allows for ambiguities, multiperspectivity, even fragmentation" (1208). However, Barnouw is not right when arguing that Iser's view is paradoxical because it puts "an emphasis on the reader's role asserting the primacy of the reader's imagination to which the text will have to submit itself" (1208). For as Iser himself clarified this point: "the literary world... is only accessible to the imagination, whereas the real world is also accessible to the senses and exists outside any description of it" (Iser, "Talk" 83).

Yet, what becomes 'particularly problematic' in Iser's understanding of the act of reading, as Barnouw argues further, is when Iser "predetermines the reader's 'significance' as defamiliarization bringing about an imaginary correction of a deficient reality" (Barnouw 1209). Iser tends to choose for illustrations of his theory only particular texts "with a high incidence of indeterminacies... thereby provoking the reader to engage in an 'intense' activity" (1209). In this respect, Iser's study "fails in its attempts to pin-point the elusive dynamic interaction between text and reader" (1209). Barnouw drives home the point that an "epistemological flaw in Iser's approach" lies also in the fact that the reader and/or the text remain "highly abstract construct[s]" presented "as if they were going on in a vacuum" (1209).

Following this, Barnouw concentrates on her discussion thesis of disappearance of text and reader in Iser's theory of the act of reading, though not very objectionably assuming that such conclusion "could be projected as the eventual result of Iser's concept of the blank and of indeterminacy" (Barnouw 1209). She maintains, though not very enlighteningly, that even when Iser takes up his favorite texts to show the dynamic process (i.e. the split between the text and reader) it is again 'problematic' for this dynamic process "must first have been envisioned by the author who plotted the strategy of the 'reverse' (Fielding's term) and integrated it in the text" (1212). However, in The Act of Reading Iser clearly says that: "The literary text... exists primarily as a means of communication, while the process of reading is basically a kind of dyadic interaction" (66). Barnouw concludes her point by raising a somewhat odd question: "A dialogue between whom? A text reduced to a self-regulatory system of stimuli, a reader who is subjected to such stimuli as if he had been lobotomized?" (Barnouw 1213) 
I think that Barnouw has degraded the interaction between reader and text; her thesis cannot stand, because the reader's encounter with a work of art is a willing encounter, and it may even be said that the reader by reason of a certain inward calling pursues such communication forms. Readers identify themselves with familiar elements inherent in the world of fiction, but these elements are reorganized in a new and unfamiliar situation. The reader tries to construct this new situation in the process of reading, for "speech devoid of situation is practically inconceivable... [f] urthermore, speech is almost always directed at an addressee-usually in an attempt to stabilize the variable factors left open by the actual situation" (Iser, The Act 62). The reader is surprised when in the process of reading he is encountered with a new and unfamiliar situation, and he continues his reading in order to find a revelatory model in the world of fiction.

We might say that a literary text is of a kaleidoscopic nature which constantly changes its pattern to each individual observer. No matter what system of stimuli a reader may be subjected to, he is not lobotomized, on the contrary, he will make himself free to create his own personal world out of the possible worlds inherent in the text. Any literary text, no matter how deceptive, disorienting, ambiguous, lacking, excessive, brings about the freedom of the reader, which results in his transformation. The transformation of the structure of the text of modern and contemporary novel indeed may be claimed to have become the image of a poetics of an open work, but as such it has brought about the transformation of the reader, too. With the modern novel, reading is not only that which is prescribed in the text; it is also that which makes possible to be interpreted in terms of the perspectives it opens up for interpretation. In this context, it might be said that any literary text transforms its reader to the extent that it regulates this transformation. This oscillation between text and reader can perhaps be said to correspond to Heidegger's conception of the 'hermeneutic circle' in his elucidation of The Origin of the Work of Art when he asserts that "not only is the main step from work to art a circle like the step from art to work, but every separate step that we attempt circles this circle" (Heidegger 18). We may reconceptualize Heidegger's 'hermeneutic circle' as an iterative process of the reader's transformation being subjected to an open-ended text of fragmentary segments. 


\section{Conclusion}

To conclude, it may be claimed that for both Ingarden and Iser the object of experience was the text and that readers can be cognizant of everything in the text as well as in their psychic operations on the text. Put differently, appreciation of literature comes from what is given in the text and from what has been stored in the consciousness (memory, perception, awareness) of the reader. The competent reader notices what is relevant, draws connections between what is given and what is lacking in the text, and makes his own decisions about the text's meaning. Namely, literature is processed in terms of our interaction with it. Yet, we should also point out the differences between Ingarden and Iser's phenomenologies of reading: in Ingarden's phenomenology the reader is a 'transcendental ego' concretizing the meaning of the imaginary object's manner of givenness. By way of their psychic operations readers fill in 'places of indeterminacy' and establish the world of the literary work of art. For Ingarden, the process of reading moves in one direction: from the real world to the imaginary (intentional) world. For Iser the process of reading is two-directional: the reader fills in the blanks of the imaginary world using the memory traces collected in his mind that derive from the life-world. Thus, the existing version of the fictive world provides the reader with a new version for the understanding of the real world. As this version of the world is constituted by readers on the basis of the text, it may be concluded that both Ingarden and Iser discovered new worlds for us to see.

\section{WORKS CITED}

Barnouw, Dagmar. "Review of The Act of Reading: a Theory of Aesthetic Response by Wolfgang Iser; The Implied Reader: Patterns of Communication in Prose Fiction from Bunyan to Beckett by Wolfgang Iser." MLN 94.5 (1979): 1207-1214.

Brinker, Menachem. "Roman Ingarden and the 'Appropriate Aesthetic Attitude' to the Literary Work of Art." Poetics Today 5.1 (1984): 129-148.

Brinker, Menachem. "Two Phenomenologies of Reading: Ingarden and Iser on Textual Indeterminacy.” Poetics Today 1.4 (1980): 203-212.

Bundgaard, Peer. "Roman Ingarden's Theory of Reader Experience: A Critical Assessment.” Semiotica 194 (2013): 171-188.

Culler, Jonathan. On Deconstruction: Theory and Criticism after Structuralism. Ithaca, NY: Cornell University Press, 1982.

Fish, Stanley. "Why No One's Afraid of Wolfgang Iser." Diacritics 11.1 (1981): 2-13. Heidegger, Martin. Poetry, Language, Thought. New York, NY: Harper \& Row, 1971. Holub, Robert C. Reception Theory: a Critical Introduction. London; New York, NY: Methuen, 1984. 
Ingarden, Roman. The Cognition of the Literary Work of Art. Evanston, IL: Northwestern University Press, 1973.

Ingarden, Roman. The Literary Work of Art: an Investigation of the Borderlines of Ontology, Logic, and Theory of Language. Evanston, IL: Northwestern University Press, 1973.

Iser, Wolfgang. “Talk like Whales.” Diacritics 10.2 (1980): 57-74.

Iser, Wolfgang. The Act of Reading: A Theory of Aesthetic Response. Baltimore, MD; London: Johns Hopkins University Press, 1978.

Mitscherling, Jeff. Roman Ingarden's Ontology and Aesthetics. Ottawa: University of Ottawa Press, 1997.

Ricoeur, Paul. Time and Narrative. 3. Chicago, IL: University of Chicago Press, 1988. Rudnick, Hans H. "Roman Ingarden's Literary Theory." Analecta Husserliana. Vol. IV. Ed. Anna-Teresa Tymieniecka. Dordrecht: D. Reidel Publishing Company, 1976. 105-119.

Szczepańska, Anita. "The Structure of Artworks." On the Aesthetics of Roman Ingadren: Interpretations and Assessments. Eds. Bohdan Dziemidok and Peter J. McCormick. Dordrecht: Springer Netherlands, Kluwer Academic Publishers, 1989. 21-54.

Wellek, René. Discriminations: Further Concepts of Criticism. New Haven, CT: Yale University Press, 1970.

\section{Konkretizacija literarne umetnine: elementi za primerjavo med Romanom Ingardnom in Wolfgangom Iserjem}

Ključne besede: literarna teorija / branje / fenomenologija branja / nedoločena mesta / konkretizacija / Ingarden, Roman / Iser, Wolfgang

Pojem konkretizacije, ki ga je v svojem temeljnem delu Literarna umetnina uvedel Roman Ingarden, prenaša na bralca odgovornost, da ustvari literarno umetniško delo kot estetski objekt. Pred bralnim dejanjem je po Ingardnovi analizi 'samo delo' večplastna struktura: plast zvokov besed, plast pomenskih enot, plast shematiziranih vidikov in plast upodobljenih objektivitet. Bralec ali bralka konkretizira delo tako, da pretvori njegovo shematsko obliko $\mathrm{v}$ dovršen estetski objekt. Do konkretizacije pride, ko se prek bralnih mentalnih operacij zapolnijo mesta nedoločenosti ter nadalje določijo sheme besedila na vseh ravneh, s tem pa vzpostavi svet literarnega umetniškega dela. Wolfgang Iser prevzame ob iskanju svoje lastne pozicije Ingardnov koncept mesta nedoločenosti in predstavi koncept nedoločenosti v obliki zevov oz. 'praznin', ki dopuščajo več funkcij in oblik kot Ingardnova analiza. Medtem ko Ingarden meni, da se proces branja premika enosmerno, od resničnega 
proti (intencionalnemu) imaginarnemu svetu, vidi Iser branje kot dvosmeren proces: bralec ali bralka zapolnjuje praznine $\mathrm{v}$ imaginarnem svetu s sledovi lastnih shranjenih spominov, ki izvirajo iz resničnega sveta. Poskus, da bi pojasnili Ingardnovo fenomenologijo branja, lahko torej pripomore k osvetlitvi Iserjevega prispevka. Ne nazadnje zasluži tematika svežo pozornost že zato, ker je pojem konkretizacije doživel številne kritike (med drugim R. Welleka, G. Pouleta, S. Fisha in D. Barnouwa).

1.01 Izvirni znanstveni članek / Original scientific article DK 82.0:028

DOI: https://doi.org/10.3986/pkn.v44.i1.08 